\title{
ECONOMIC AND SOCIAL ETHICS IN THE WORK OF JOHN CALVIN
}

Author:

Matthias Freudenberg ${ }^{1}$

\section{Affiliation:}

${ }^{1}$ Theological Seminary,

Wuppertal, Germany

Correspondence to:

Allan A. Boesak

e-mail:

boesak@mweb.co.za

\section{Postal address:}

Postnet Suite 285, Private Bag X15, Somerset West 7130 , South Africa

\section{Keywords:}

economic and social ethics; Calvin; reformed Protestantism; economic processes; globalisation

\section{Dates:}

Received: 21 Aug. 2008 Accepted: 10 June 2009 Published: 06 Nov. 2009

How to cite this article: Freudenberg, M., 2009, 'Economic and social ethics in the work of John Calvin', HTS Teologiese Studies/Theological Studies 65(1), Art. \#286, 7 pages.

DOI: 10.4102/hts.v65i1.286

This article is available at:

http://www.hts.org.za

Note:

This contribution was originally presented during a consultation of the Joint Globalisation Project of URCSA and the ERK at the Evangelical Academy Arnoldshain, Germany, on 26-30 May 2008. It was requested by the research group as a theological and ecclesiological assessment of the "The Accra Confession: Covenanting for justice in the economy and the earth', www.pkn. $\mathrm{nl} /$ site/uploadedDocs/ TheAccraConfession.pdf, viewed on 15 September 2009. The original German of this article is translated by Eiwin Scholl from Emden, Germany.

(c) 2009. The Authors. Licensee: OpenJournals Publishing. This work is licensed under the Creative Commons Attribution License.

\section{ABSTRACT}

John Calvin and Reformed Protestantism interlinked questions of life and death with questions of faith. Not only faith and the church, but life in general call for constant renewal through the word of God. These processes of renewal incorporate society and the economy. In contrast to the popular assertion that Calvin and Calvinism are responsible for capitalism and its aberrations, Calvin in particular shows a deep sensibility for human beings trapped in economic deprivation. In his sermons Calvin exhorts the rich to consider the poor as 'their' poor and to thank God by practicing generosity. This appreciation of social questions within an ecumenical context is demonstrated in the Reformed church in a whole array of charitable services. It will be crucial for the current debate on economic ethics to assess economic processes in relation to how they serve life. For it is liberty, justice and fellowship - as gifts of God - that serve as an orientation and an obligation to be aware of human beings suffering from the negative consequences of globalisation.

\section{INTRODUCTION: THEOLOGICAL FOUNDATIONS}

I would like to start with the impression created by some Dutch paintings of the $16^{\text {th }}$ century. After iconoclasm had raged through the Dutch churches in 1566 and as the Calvinist church buildings remained devoid of images, artists as a rule turned to secular subjects. If religious themes were depicted it usually was done with a moral educational intention. An example is the portrayal of wealth and poverty. The painter Hans Vredemann ${ }^{1}(1526-1609)$ took up the parable of the rich man and the poor Lazarus several times. In the first painting (Ill. 1: Lazarus and the rich man, 1572), the poor man is seen begging in vain for leftovers in front of the rich man's mansion while inside a sumptuous dinner party is taking place. Dogs are used to bar him from the realm of the wealthy.

In another painting with the same theme (Lazarus in front of the rich man's mansion, 1583) the rich man is depicted behind iron bars, burning in hell. The pedagogic intention of the painting is evident: wealth carries with it the danger of perdition. One cannot fail to notice in this painting an indication of the ideals of restraint and modesty which were increasingly accentuated in Calvinism.

Against this background the question is what the specific Reformed measures concerning wealth and poverty and the economy amounted to. According to classic Reformed understanding economic questions cannot be left to inherent economic logics. They touch on the basics of the Christian faith and can become the subject of confessing and the confession of faith, since questions of lifestyle are closely connected with questions of faith.

According to John Calvin, not only faith and the church but also life as such are in constant need of renewal by the word of God. All dimensions of everyday life are included in this process of renewal. In the Calvinist strain of the Reformation Karl Barth recognised the logical step from the cognition of God to the reality of human life. This step made Calvin and the Zurich reformer. Ulrich Zwingli, 'prophets of the new Christian ethos'. Barth added that Calvin, who had turned his attention to the reshaping of the world, 'made the Reformation qualified to operate in world and history' and, in the shape of Calvinism, to exert a major influence on the social theories of the modern age.

Through the dialectics of cognition of God and of the human self, Calvin's theology does not contain a bipolarity in which human life is set in relation to God's life. God exists on behalf of human beings who in turn live in the presence of God and for God. For Calvin a Christian life is not led under the pre-signification of an exacting and authoritarian ethical imperiousness. He describes the sanctification of the lives of human beings as God's liberating work for the benefit of human beings. The purpose of God's work is human freedom, which is the sign of a truly Christian existence. A life lived to honour God and the Christianisation of the world are based on faith in God who, in Jesus Christ, put his own life at stake for the benefit of human beings. Humans were created to respond to the Creator and Guardian of their lives with the gifts entrusted to them and, in gratitude, to bear resemblance to God.

The church of Jesus Christ exists in a world in which poverty and wealth, and unjust and just circumstances can be perceived and identified. From its inception an identity marker of the Christian church was to be defender and partner of the weak and the destitute. This applies to Christianity in its worldwide dimensions as well as in its Christian social service of relieving need locally and in a broader context. Diakonia (Christian social service), especially when embedded in the local congregation, is an important aspect of church life.

\section{ECONOMY IN THE BIBLE}

Economic questions have their place at the centre of Christian faith and are an important topic in biblical theology. The Old Testament already deals with economic questions such as, for example, the law of obligations, interest, credit and insolvency and criteria for dealing with them with just action

1.See Dutch \& Flemish art in Russia, Foundation for Cultural Inventory (Stichting Cultuur Inventarisatie), Amsterdam, viewed on 19 September 2009, from http://www.codart.nl/downloads/Dutch_and_Flemish_art_in_Russia_part_1.pdf. 
and judgement (cf. Ex 22; Dt 24). In this way the social and religious community of the Israelites was to be kept intact. They see themselves as a people touched by God's kindness, bound by in the Covenant of Mount Sinai and the instructions of the Torah, and destined to shape their lives in faithfulness to their Redeemer.

One of the central fundamental economic rules is the introduction of the Year of Jubilee or the Sabbatical Year (Lv 25, Dt 15). This entails a remission of all debts at regular intervals in order to prevent the continuous accumulation of wealth or debt. Throughout the Bible the economy is seen from the point of view of poverty and the existence of people living in economic need. Poor people have a right to justice (Am 2:6) and can expect the solidarity of the national and religious community (Is 58:1-12; 61:1-11) as well as specific reductions and disburdening (Ex 22:24; 23:10-11; Lev 5:7-13; Dt 23:20-21; 24:19-22; Neh 5:1-13). According to New Testament testimony, Jesus took up the concept of the Year of Jubilee ( $\operatorname{Lk} 4: 19)$. It emphasises Jesus' particular mission to the poor (Mt 11:5; 25:40; Lk 4:18; 16:19-31; 18:18-27), the installation of the overseers of the poor (Ac 6), the self-appellation of the first Jerusalem congregation as 'the poor' (Gl 2:10) and the collection for the poor (1 Cor 16:2; 2 Cor 8-9). These examples clearly show that economic issues are dealt with in the texts of the Bible, with special attention to the fate of the poor.

In early Christianity the finances of the congregation (Ac 6), financial equity among the congregations (2 Cor 8-9), the treatment of slaves and the conduct of the wealthy towards the poor at the Lord's supper (1 Cor 11:17-34) were on the agenda. According to Paul, the Gospel is at stake in how the congregations see themselves and their purpose. Proclaiming the Gospel, communion, congregation and diakonia were interconnected.

This biblical sensitivity concerning economic questions was taken up by the Christians of the first centuries. So John Chrystostomos saw himself as a defender of the poor, called compassion the mark of humanity and declared that Christ himself encounters human beings in the guise of the poor. ${ }^{2}$

A difficult issue was that of lending money with interest. In Aristotelian tradition, following the Old Testament's prohibition of usury, Christians were not allowed to charge interest. The biblical passages in question already demanded that the poor should not be exploited for the economic advantages of the wealthy (cf. Ex 22:25; Lk 19:23) - a matter that is still valid in the present situation of economic globalisation, especially when viewed in connection with the debt crisis.

\section{ECONOMIC AND SOCIAL ETHICS AFTER THE REFORMATION}

In many towns of the late middle ages a high percentage of the population was extremely poor and had to beg for a living which was most uncomfortable for the wealthier citizens. When society had changed on account of the new money economy and the diversification of urban civilisation, social problems could no longer be solved by the traditional means of 'evangelical counsels' (of the Roman Catholic Church) - in other words entering a monastery, giving alms and doing good works. Begging and alms-giving were subject to humanist criticism. They were seen as a deviation from the virtues of the new urban society, such as industriousness, orderliness, discipline and modesty.

In addition, economic ideals and the monastic ideal of poverty were at odds. The latter was criticised by supporters of the Reformation. The conviction was growing that showing kindness to the poor was the consequence of the new understanding of

2.See 'The glory that was - and is - new Rome: Fifty holy patriarchs witness to the Orthodox faith', viewed on 19 September 2009, from www.orthodoxengland.org. Orthodox faith', viewe
uk/newrome.htm. the Christian faith that transferred its activity of grateful charity from the individual to the congregation. Furthermore the contours of what was to become Calvin's attempt to deal with social issues were slowly emerging: work, a modest and frugal lifestyle, and brotherly love - virtues that now increasingly asserted themselves and were able, at least partly, to address the ills of poverty.

With his criticism of the medieval monastic attempt to solve the social problem, Calvin followed in the footsteps of Martin Luther. Luther, with his concept of the righteousness of God, divested good works of their meritorious character, removed relief of the poor from the realm of merit and added it to the fundamentals of faith. When he called for an end to begging in his 1520 'Address to the Christian Nobility of the German Nation' it brought about a stagnation of the income of the mendicant friars and towns took over the social responsibility. The relief operations of the monasteries were often taken over by the towns or transferred to the responsibility of the Christian congregations. The old begging regulations were supplanted by obliging regulations concerning the poor. One result of this process of reform was the establishment of the Wittenberg ordinance on poor relief of 1520/21 and the Leisnig ordinance of 1523.

Luther, however, did not recognise that the serfdom of the feudal system was a reason for poverty. Therefore he did not see the abolition of serfdom as an objective of the Gospel - rather, abolition of serfdom would profane Christian liberty. Although Luther held the conviction that God was a god of the poor and not of the rich it seems that he thought less of material but rather of spiritual poverty as found in the Sermon of the Mount. Therefore Luther did not endeavour to develop a solution to poverty from guidelines from the Gospel which would fit the social circumstances of his time. More impulses were needed on the way to a spiritual diaconal system which would be the responsibility of the entire congregation before poverty would be seen as a subject for the ecclesiology and social ethics of Reformation theology.

These impulses came from Switzerland and Southern Germany. Zwingli diagnosed poverty as an effect of the Swiss mercenary system. He argued that voluntary service in foreign armies destroyed the social and economic fabric of the country, as able-bodied young men were called up for an indeterminate period of time and then sent back home with quite meagre pay. His criticism of monopolistic economy, monetary policy, high taxes and land tax resulted in his call for fundamental reform of Church and society.

Martin Bucer showed a similar understanding of the demands of the peasants. He wrote on the situation of the peasants in his Gesprechsbiechlin (conversation booklet) of 1521 in which he had a peasant tell his story of poverty and its roots in feudal exploitation. This was the beginning of what later became a political claim, when Katharina Zell, Wolfgang Capito and Bucer demanded mercy for the poor in Strassburg. A practical consequence of this intervention was the act of opening the city gates to refugees from the countryside. A prominent role in poor relief was played by Katharina Zell who was the main representative of a new female diaconate. Strassburg was also the place where the roots of Calvin's social ethics lay.

\section{CALVINISM AND CAPITALISM}

The sociologist Max Weber's theory of a conjunction between capitalism or economic success and Calvinism still enjoys great popularity. The alleged temporal asceticism of Calvinists, together with the doctrine of double predestination, is claimed to inevitably contribute to economic success. Following Weber, Ernst Troelsch describes Calvin as a prototype of someone who with his reasoning has given an impetus to the process of economic development. In many encyclopaedias this theory is often repeated uncritically. However, Weber's idea of attributing 
the spirit of capitalism to the so-called Calvinistic inner-worldly asceticism, and attributing the endeavour for economic success to the idea that one was already predestined for success, does not withstand critical scrutiny. Calvin's deliberations on the question of economic justice and the relation between the rich and the poor cannot be seen as encouraging unrestricted capitalism. In view of the popular Weber theory as well as the socio-ethical challenges of the present time, insight into Calvin's theological argumentation is needed in order to come to a wellfounded assessment of the classic Reformed contribution to the ethics of economy and society.

\section{CALVIN'S SERMONS}

Calvin attentively perceived the social effects of the economy in Geneva. 'Almost everyone whose wealth allows him greater expenditure finds his delight in luxuriant splendour.' With these words he castigated the expensive lifestyle of the wealthy and accused them of perverting Christian freedom. The situation in Geneva around 1555 was characterised by the beginning of an economic upswing, with refugee immigrants having a considerable share in it. The disadvantages of this upswing were growing social tensions, problems of integrating the mostly poor refugees, a housing shortage, poor marketing opportunities for the tradesmen, a shortage of ready money, debt burdens and inflationary tendencies. Geneva at the time was going through an upheaval with a disparate societal structure, including the reality of poverty which burdened large segments of the population.

Christian faith had to respond to the situation. Calvin's ethical deliberations on the economy are based on the idea that all human relations and actions are under the dominion of God, who is the source of all human communal life. Individual and communal life is to be led in Christian freedom, thereby honouring God and showing gratitude. This is especially relevant for a community where the poor and the wealthy live together. By emphasising the obligation of the wealthy to help the poor with the gifts entrusted to them, Calvin attempted to give scriptural direction to the lives of the poor and the wealthy. His theological contemplation on wealth and poverty was expressed in his sermons on Deuteronomy in 1555/6.

He spoke rather extensively of poverty in his sermon of October 1555 on Deuteronomy 15:11-15, a text which deals with the year of release and freeing the slaves. He began by explaining that the sentence 'The poor will always be with you in the land' (Dt 15:11) does not mean a fatalistic resignation to poverty. Resignation in the face of poverty is more than just carelessness. It constitutes the sin of a lack of charity, a self-immunisation against poverty and of avoiding being confronted with it. The words on enduring poverty were spoken in order to encourage Christians to do what is necessary to fight poverty rather than just talking about it. Poverty cannot be romanticised and Calvin calls for its abolition. The question is how the words about enduring poverty are to be understood. Calvin does not see it as a perpetuation of the status quo, but theologically it points to a secret of God that cannot be explained by human theories.

This secret that is revealed in the existence of the poor must be seen as a fact that cannot be explained. Calvin concludes that this secret is not meant to depress and paralyse but rather to lead to a life according to faith.

Calvin seeks a theologically feasible way not to judge the poor or poverty but to find a place for the poor in their relation to God and to the rich. His idea of this relationship is as follows: as simultaneously Lord of the poor and the rich, God wants to test the rich. As they have been given their wealth by God, they should be careful not to use it as an instrument of power against others. The rich are to recognise that the very existence of the poor challenges them to generosity and charity. On the other hand the poor are challenged to master their fate in patience and not to try and alleviate it by robbing or cheating. Therefore the idea of divine pedagogy pertains to both the poor and the rich.

Despite all attempts to explain the problem of poverty, it remains a secret that with Calvin's interpretation is transformed into a challenging theme of the right worship of God and of Christianity in action. God sends the poor as God's own messengers so that the wealthy give directly to God when they give to the poor. The theological gain of this interpretation is clear. The poor and the rich are brought into relation with each other. As an exigent part of life the rich need the poor whose very existence is more than just a challenge to their material resources. Poverty calls on the rich and on the whole Christian community to interpret their own existence in the presence of God.

The critical objection could be that this theological reasoning obscures an underlying affirmation of unjust social conditions. They are actually sanctioned by means of a religious elevation of poverty. In fact, Calvin warns against a revolutionary liberation from poverty. On the other hand the practical consequences were, for example, that begging was stopped, and that hospitals, orphanages, schools for children and alms-houses were established. All of this had been done in Geneva from 1535 onwards. The diaconate was seen as the administration of gifts and as direct help in need. This underlines Calvin's vision to fight and overcome poverty. In this concept there is no ecclesia without diakonia. But even with the best system of poverty laws and their related institutions the problem of poverty was solved.

Calvin impresses on the Christian church to recognise the poor as its poor: 'There is a reason for the Lord to say: to thy poor, and to thy needy, in thy land. It is the Lord who presents them to us.' It remains a thorn in the flesh of the Christian church that the poor and the rich are bound together by the Lord and as such should have communion with each other and should honour God by their existence. As they both need each other the removal of their contraposition is the greatest commandment. Furthermore it should be prevented that the subject of poverty is objectivised in such a way that a community is classified according to poverty and wealth and that the poor individual is passed over in silence, pushed to the margins and shunned from the presence of the wealthy. Encountering one another, communication, receiving and giving, sharing - those are the dimensions in which everyone's life is to be lived in God's presence - so that 'they both praise God when the rich are able to do good and the poor give thanks for it'.

The poor and the rich, both with their particular possibilities, together form a living organism in which their communio presents itself as a virtual 'spiritual miracle'. The background for this model is the perception that all wealth, as gifts of God, is not left to free disposition but is entrusted to people for sharing with others for the common good. Whereas the honour of God forms the first focal point, communion and humanity mark the second focal point in Calvin's sermons on socio-ethical matters. Calvin focuses on the reality of the poor and the rich in their communio and humanity in God's presence, which challenges the rich to ask: 'What if I were in need now?' Calvin's answer to that is: 'We all are to be human.' Human beings are seen here as humane and communicative beings.

In his sermon on Deuteronomy 24:14-18 held on 10 February 1556 Calvin takes up the concept of humanity. He speaks of the actual situation of dealing with poor people in their working conditions, sides with those whose wages are being withheld, and theologically establishes the right to just remuneration, as God has decreed consideration for the need of every individual. Taking up the golden rule, this means that the wealthy shall put themselves in the shoes of the poor and rectify their relation to the poor according to the principle of equity. Socio-ethical problems challenge faith and are to be found in the sphere of justice before God: 'The cries of the poor (needs must) rise up to heaven, and we must not think to be found without guilt before 
God'. Because God sides with the poor, the rich rebel against God if they disregard the right of the poor and do not confirm their humanity. Compassion with the poor becomes the mark of humanity for the rich.

In his sermon on Deuteronomy 24:19-22 of 11 February 1556 Calvin emphasises several aspects. Firstly, God has entrusted the goods to the wealthy in order to enable them to let their poor neighbours share in their resources. The poor and the rich are seen as connected to each other in a close mutual relationship and therefore not dissociated before God or from the Christian community. The foundation of this relationship lies in the fact that all wealth comes from God and therefore should be employed for the benefit of others. God's covenant with human beings is directed towards the humanity of people caring for one another.

Secondly, the gifts received connect the wealthy to God as the donor in a covenant that is characterised by gratitude. This divine law encompasses the practising of a human order with consequences for the poor and for the rich: for the poor, that they do not misappropriate the goods by force; for the rich, that they have the duty to share. Divine law and human order are being brought together in a connection that resists a moralistic attitude and describes the co-existence of the poor and the rich as a mutually promising task.

Thirdly, dangers to which the rich can succumb are avarice, miserliness, being overbearing, and lacking gratitude. Calvin exposes these sins. In contrast, those who are favoured with the necessities of life should see this privilege as a God-given blessing.

Fourthly, the concept of the communion of the poor and the rich in the Church of Christ, based on human beings having been created in God's image, aims at a communio sanctorum that is not yet realised. In this concept of a diagnosis of the present time and a vision of the future the category of remembrance is included: Egypt, the poverty of the Israelites and the exodus form an image of remembrance of need and poverty, but also of deliverance and the promise of land and ownership. In the biblical context of Egypt, the exodus, the covenant of Sinai and settlement in which God pledges God-self to God's people, the rich shall recognise themselves as endowed and the poor as redeemed. The deepest reason for Christian charity and humanity lies in the common basic human condition of elementary indigence. We all stand together before God as indigent beings to whom the new life, instituted in Jesus Christ, has been granted. True humanity is made possible by God's humanity.

Calvin's fundamental socio-ethical idea develops quite clearly: on the one hand God's humanity induces people to be humane. On the other hand all people are identified as basically indigent before God, regardless of their economic status. True humanity is a humanity of indigence. This is based on the proclaimed word of God's incarnation and humanity, and consequently is a humanity based primarily on the Gospel and not on a moral plea.

\section{CALVIN AND MONEY, PROPERTY AND INTEREST}

When Calvin speaks of property and money he departs from an important presupposition: property belongs to God. That is also the case for humankind. All people belong to God and are God's property - they themselves as well as their particular personal gifts and possessions. From this position Calvin takes his stand on material property. In Geneva money was an acceptable topic for conversation. Economic issues were not considered taboo since they were of concern to the people. Calvin does not place money and property in a negative light. His approach displays a sobriety in which money and property are neither glorified nor condemned. He keeps two things in mind: the often desperate situation of the poor and the logic of the market, including a moderate interest rate. He denounces the medieval monastic idea that a self-determined renunciation of property would result in special merits with God. That can clearly be seen in his explanation of the passage on the rich young man (Mt 19:16-22) a passage to which medieval monastic theology often referred.

Calvin opened up new perspectives on economic ethics with his emphasis on the following: in principle Christ does not call for people to get rid of their possessions - this could even foster vanity - but what God has given to people should be kept in good condition. Therefore Calvin calls on people 'to make use of God's gifts without a bad conscience'. Goods and resources are given to be used. Nowhere is it forbidden to acquire property. However, Calvin does set boundaries for freedom by warning that Christian liberty should not be corrupted through frivolous luxury, squandering of entrusted goods, or avarice. Neither unrestrained use nor ill-considered renouncement of liberty is compatible with a Christian understanding. Liberty is, according to Calvin, a restrained liberty - restrained by the Redeemer's will and therefore also restrained by the relation to others. Freedom should never be used against others, but should be utilised for the welfare of others according to the criterion of charity - Calvin speaks of 'moderation in liberty'.

Money, property and wealth are no hindrance to entering into the kingdom of heaven. On the contrary, heaven is open to the poor and the rich. Property as such does not constitute a problem, since it is a gift from God. Therefore Calvin can also praise the merit of property and, for example, emphasise the beauty of clothes or the effect of cosmetics. Delight in these gifts from God, not suspicion, determines his view. To just throw away wealth is not an extraordinary achievement. But charity - giving wisely and generously - is the yardstick for the use of property and money. In his Genesis-explication Calvin warns: 'Let us take heed that wealth may not lie heavy on us and become an obstruction in the way to the Kingdom of Heaven'.

Gratitude is added to Christian love as a yardstick for the employment of money and property. Gifts should be received and used with gratitude. In his interpretation of the parable of the rich man who decided to build greater barns (Lk 12:16-21) Calvin puts it as follows: 'Therefore everybody needs to awaken himself that he does not count himself blessed because of his wealth'. In order to fare well in life one needs more than just economic well-being. Thus Calvin warns against putting one's trust in temporal goods and ignoring the Giver of the goods.

Calvin does not agree with the saying, widely propagated in antiquity, that money does not generate money. He thinks it meaningful to place start-up capital at the disposal of entrepreneurs and to make economic promotion possible through credit. In this way he supported the integration of qualified small tradesmen and businessmen who had come to Geneva, partly as destitute refugees. These measures touched on the question of paying interest. The Reformed perspective on the subject of interest, starting with Calvin, on the one hand aimed at regulating widespread and unjust usury and on the other hand had to pay attention to the biblical position against asking interest (Lk 6:34). Calvin denied that the Bible demands a total ban, and pleaded for money to be allowed to make a profit, just like other possessions. Interest could even be an economic motivation to invest money productively. He demanded fairness when charging interest. Only those who are economically capable of paying interest should do so; no interest should be asked of the poor. According to him, the state has the task of overseeing the credit system and to regulate the interest rate.

n summary, it can be stated, firstly, that property is a good gift and blessing from God. It may be enjoyed, utilised and passed on with free responsibility. This should be done according to the yardstick of charity and gratitude. The mutual sharing of gifts in the congregation rests on the principle of free will. A 
forced expropriation would be in fundamental opposition to Calvin's thinking that expressly supports the right of ownership.

Even when, secondly, the difference between the rich and the poor remain, the contraposition of the two should be overcome. To put it in concrete terms: avarice, contempt for the poor, and frivolous showing off of luxury are contrary to the principle of charity, according to which possessions should be used. Therefore Calvin opposed any practice that could harm the poorest segment of the population. He called for a balance between economic upswing and social justice.

Thirdly, economic rules, such as asking interest, need to be regulated in order to remain legitimate. The legitimate money economy should be brought into harmony with the biblical commandment to care for the destitute.

\section{PRACTICAL EFFECTS}

'We do not belong to ourselves but to God.' This is a concise summary of Calvin's economic and social ethics. The Christian congregation, divided into rich and poor, confess the living God as their Lord according to whose promises they live and to whom they are duty-bound.

Calvin's theological perspectives on socio-economic matters should be evaluated according to their practical and institutional outcomes. Reformed Protestantism was not content with the discrepancy between rich and poor in society. The idea of humanitas and communio of people living in different economic and social contexts took form. In Geneva, for instance, besides the early modern age's existing measures for social equity, assistance was given to religious refugees who were passing through. The Geneva church order of 1561, which expressly saw itself as 'deduced from the gospel of Jesus Christ', described the office of the deacons as the fourth estate in the guidance of the Church and assigned to them the task of being goods-managers and taking care of the sick and the poor.

John a Lasco, a humanist nobleman who for a time served as East-Frisian superintendent, can be taken as an example. He was ashamed of not having been successful in implementing a regular relief of the poor in Emden. In 1549 he emigrated to London where he was installed as superintendent of the Protestant refugee congregations. His church order was his main theological work, which had an influence on Protestantism far beyond London. He gave form to Calvin's idea of humanitas and communio by developing the congregational diaconate. $\mathrm{He}$ instituted an 'office of the table for the needy', a diaconate office to alleviate misery.

The rich were recommended to give willingly and plentifully in the spirit of Christian charity, particularly since their possessions were God's property. The poor were called to gratefully receive the gifts with a good conscience and without being ashamed, since they were given as if out of God's own hand. The mutual office of the poor and the rich, as described by Calvin, became institutionalised: they both honoured God by their generosity and their gratitude respectively.

For a theological understanding of relief to the poor, the prayer at the induction of the deacons is significant: 'Lord Jesus Christ, you have commanded us, recognising yourself in us poor believers and our poor ones as yourself, to take special care of them in your Church ...'. The next sentence ends with the prayer '... that they (the deacons) will serve your poor among us religiously and faithfully.'

The Christian poor relief was founded on Christ bestowing kindness on the poor, was motivated as being an act of discipleship, and was seen as the joint office of the congregation. At the end of every church service the liturgical admonition to remember the poor and to pray for them was expressed. It was the duty of the whole congregation to show mercy. After his return to Emden, John a Lasco instituted a 'Diakonie der Fremdlingen Armen' (Diaconate of the Destitute Strangers) according to the London model; other institutions for the infirm, orphans, and transient poor followed. In the Emden church order of 1571 we find the instruction that the congregation shall not relieve itself of the poor refugees by recommending them to other congregations. All these examples show the importance that was attributed to the care of the economically infirm and socially uprooted.

\section{ECUMENICAL DISCUSSIONS}

It is an undeniable merit of Roman Catholicism that the Second Vaticanum and the social encyclicals have attached special importance to the question of poverty. The opening up of the Roman church to the world (aggiornamento) has had an influence on church and theology seeing social problems as a challenge, especially in Central and South America. In the decree on the apostolate of the laity 'Apostolicam actuositatem' (1965) the assignment of the Church to combat poverty, suffering and misery in all their forms was described as a mandatory charitable action and as a witness to the world. The constitution 'Gaudium et Spes' (1965) argues in a similar way.

These conciliar impulses were inspired by liberation theology, as it found expression in the works of Leonardo and Clodovis Boff and Gustavo Gutiérrez. They described the necessity to focus on social reality, to reflect critically on the practice of theology, and to understand Jesus Christ, who identified himself with the poor and miserable, as the liberator of the conditio humana. The reality of Christ and the reality of the poor are the fundamental realities that apply to discipleship. Structural transformation and direct aid efforts are identified as social-ethical perspectives. But most important was the theological question: What implication does the reality of the poor have for the entity and the activity of the church? Gutiérrez demanded: 'Only if the Church repels poverty and becomes poor herself in order to protest against poverty will she be able to preach what is particular to her, the openness to the future promised by God.' The fruits of these theological efforts were laid down in the documents of the bishop conferences of Medellin (1968) and Puebla (1979).

The 'Document of Medellin's connects the subject of poverty with righteousness and peace so that the hunger and thirst after righteousness' and peace do not only activate more welfare activity but also involve the structural transformation of the social fabric. The manifold poverty of humankind is set in context with the suffering of Christ. Just as Christ had made himself poor so also the Church is called to exist as a poor church. The 'Document of Puebla' built on this statement. In this document the 'great gulf' between the rich and the poor is denoted as sin, and identification with the poor and with Christ is called for. The document explicitly speaks of the 'priority of opting for the poor'. The Christological reason for this is based on the incarnation and poverty of Christ as well as his turning to the poor.

But what exactly does the document mean by 'priority of opting for the poor'? More than just works of Christian charity is needed. A comprehensive righteousness that goes to the root of the problem of poverty should come into focus. The point of the 'priority of opting for the poor' is to make poverty a constituent part of the proclamation of Christ and to inseparably connect faith and justice.

The documents of Medellin and Puebla give the ecumenical discussion a threefold task: firstly, calling for an analysis of

3.See The Church in the Present-Day Transformation of Latin America in the Light of the Council, vol. 2, Conclusions, the official English edition published by the Latin American Bureau of the United States Catholic Conference and the General Secretariat of the Latin American Episcopal Council (CELAM). The Genera Secretariat of the Latin Ammedican Conference (Second General Conference of Latin American Bishops) took place English translation appeared in 1970, viewed on 19 September 2009, from law.loyno. edu/ quigley/Class/classjusticepeace.pdf. 
structural poverty, secondly, connecting poverty with justice, and thirdly, finding a Christological foundation for the 'priority of opting for the poor'.

\section{CONTEMPORARY REFORMED ECONOMIC AND SOCIAL ETHICS}

Although the churches in Germany have taken on the discourse on the 'priority of opting for the poor', their theological arguments have occasionally remained somewhat unfocused. However, the joint statement of the churches 'Für eine Zukunft in Solidarität und Gerechtigkeit' (1997) (Towards a future in solidarity and righteousness), ${ }^{4}$ certainly has its merits. It motivates the 'priority of opting for the poor' by emphasising the human dignity of having been created in the image of God, and the commandment to love God and one's neighbour. But the argument is immediately narrowed down with churches in mind. The option for the poor is reduced to a vague 'criterion for the obligation to become active'. 'The option' means 'to overcome exclusion and to enable everybody to participate in the life of society'. The specific contribution of the churches is to give full backing to this guiding principle of social responsibility. Although the social analysis shows commendable depth, the document remains vague at the crucial point of having to expand theologically on the formula 'priority of opting for the poor'

Again it can be helpful to cast a glance across borders. The churches united in the World Alliance of Reformed Churches have, since their General Assembly of 1997 in Debrecen, Hungary, ${ }^{5}$ put the subject of a just economy on their agenda and have played a part in forming an ecumenically responsible opinion on the global economy by stating: 'Today we call the member churches of the WARC on every level to an obliging process of increasing perception, clarification and of confessing (processus confessionis) regarding economic injustice and ecological destruction'. Following the motto 'pluck asunder the chains of injustice', poverty, justice and economy are reflected on theologically. The outcome is articulated as follows: 'We do not belong to ourselves. We know that Jesus Christ has paid dearly for us. We do not want to treat anybody condescendingly, to exclude anybody, or ... to ignore the gifts of any person. We declare our solidarity with the poor and with all those who suffer, are suppressed or excluded.' This process was continued at the next General Assembly in Accra, Ghana in 2004. ${ }^{6}$ The resulting Accra Confession, a 'confession considering economic injustice and ecological destruction', submits the present system of the world economy and the dominance of the imperium to harsh criticism.

In these processes the basic Reformed testimony becomes evident, namely that the confession of faith is trustworthy and that God declares God's solidarity with those who lose out in a globalised economy. The present discussion suggests two conclusions: firstly, the duty of the rich to act in the interest of the poor. This is connected with the 'priority of opting for the poor', which is based on the specific attention that God allocates to the economically weak. Here the ecumenical discussion takes up a concern for which both biblical texts and Calvin's regard for a humane economy have set the tone. Secondly, awareness is growing that decisions made by institutions should be put into practice in congregations. Economic processes should never cause a split in congregations.

Consequently the position of Reformed Protestantism is to participate in shaping the economic order and, at the same

4.'Für eine Zukunft in Solidarität und Gerechtigkeit', 1997, Wort des Rates der Evangelischen Kirche in Deutschland und der Deutschen Bischofskonferenz zur wirtschaftlichen und sozialen Lage in Deutschland, viewed on 19 September 2009, from www.ekd.de/EKD-Texte/sozialwort/sozialinhalt.html.

5.See WARC 1997, 'The declaration of Debrecen. Adopted by the 23rd genera council, Debrecen 1997, viewed on 18 September 2009, from warc.ch/where/23gc/ declar.html.

6.See WARC 2004. 'A continuing journey towards confessing movement for economic justice nd life on earth: Covenanting for justice in the economy and on the earth (processus confessionis)', viewed on 18 September 2009, from http://www. kairoseuropa.de/english/continuing-journey.doc. time, to develop a critical consciousness for its dangers. Arthur Rich, Reformed scholar in the field of economic ethics in Zurich, advocates an ethos of humanity based on faith, hope and love in the sphere of the Kingdom of God. From this position he determined the ethical dimensions of the economic order. Contrary to an economism that sees the economy as a system of self-contained processes he asserts that the economy is made for human beings and not human beings for the economy. The question, 'What is justness for human beings?' thus becomes the basic question of economic ethics.

Justness for human beings is determined by two basic qualities: liberty and solidarity. According to Rich the fundamental aim of all economic activity is what is helpful for the lives of human beings. Concretely this means that in the economic processes several purposes may be valid, but none of these purposes should be exclusively valid. Some of these purposes are the humane, the social and the ecological aims of economic activity.

What constitutes justness for human beings? What is appropriate economically? What is ecologically just? These three questions form the triangle of an ethically responsible economy. It is imperative that Christian social ethics do not just put up with the existing economic order but actively shape the world for the purpose of promoting human dignity and love of one's neighbour. For this, theology and church have to take note of the ongoing social and economic transformation of the industrial societies and to analyse this with competence. This should happen in the framework of a Christian understanding of liberty that not only aims at individual liberty but also at solidarity.

A central theological concern is what, from the perspective of the Gospel, is right for the world. That would include the issue of justly operating the economy. Christians who know that they are called to a just operation of the economy will take a considerate, inquiring and pragmatic position in which the market economy is neither demonised nor idolised. What does it mean for the shaping of a global economy when they profess God as the incarnate Creator and Sustainer of all life? What does it mean for the relationship between the rich and the poor when they profess God as the God of righteousness. They will shape the economy 'for the benefit of humankind'. They will listen to the written and proclaimed word of God and they will discern the signs of the times.

\section{LIBERTY, JUSTICE AND KOINONIA AS THEOLOGICAL MARKERS}

What can be done so that the formula 'priority of opting for the poor' will not deteriorate into just another rhetorical stereotype, but will fulfil its theological potential? Following Calvin, three theological markers will be presented here. The presupposition is that a just operation of the economy should be orientated towards the Gospel as the good news of God's liberation, righteousness and communion, from which follows the injunction to justness. Theological reflection, rather than a pragmatism characterised by theological amnesia, is called for. Reformed sobriety rather than noncommittal norm setting or hasty appeals is necessary.

The first marker may be called the gift of liberty. Together with Israel the Christian faith remembers the exodus as the basic act of God's liberating work. In the exodus God turns to the destitute and oppressed, chooses them to be 'a peculiar people unto himself' (Dt 14:2) and obliges them to faithfully keep God's covenant. Keeping the covenant means respecting the right of the poor - an obligation that is expressly founded on God's liberating work in the exodus - and always keeping the poor in mind.

According to the witness of the New Testament, Jesus began his work, with reference to Is 61:1-2, as the fulfilment of the Year of Jubilee, that is, the Time of Salvation in which it is required to proclaim the Gospel to the poor and to announce to the suppressed their liberation. 
Just as liberation epitomises the mission of Jesus, so the gift of liberty finds its mark when it is used correctly and when it stands the test of active service in the spirit of Christian love. Compassion and communion with the poor are founded on the gift of liberty as the sign of God's free grace. The gift of liberty incarnated in Jesus Christ reminds both rich and poor of the elementary indigence of human life. In the sphere of the freedom granted by God, the promises and the obligation to participate in God's freedom and to be accountable are opened up to Christian faith.

The implementation of God's free grace which, according to thesis VI of the Barmen Theological Declaration, is assigned to the Christian community as a whole, includes the development of a culture of liberty and of mercifulness which is neither characterised by a paternalism that makes objects of the poor nor by the legalistic gesture of moral appeals. On the contrary, a culture of liberty and mercifulness will keep alive the recollection that all creation, including humanity in its social differentiation, is being led towards final liberty. Thus liberated - and being mindful of this liberation - human beings are related to God and their neighbour and not isolated. Christian liberty originates with God and is transferred to God's image, fellow human beings in the completeness of their personality. In this consequence the Christian proclamation of liberty encompasses the responsibility of the rich for the poor and vice versa. But Christian liberty also demands a corresponding political freedom without which a sustainable alleviation of the plight of the poor is unthinkable.

The second marker may be called the gift of righteousness. According to the Judeo-Christian understanding righteousness, just as liberty, is first of all an attribute of God's being and actions. In the Psalms this righteousness is praised as universal and everlasting. God's righteousness enables people to do what is good with the aim that human justice, especially regarding the poor and with those who deserve mercy, corresponds with divine righteousness. According to thesis $\mathrm{V}$ of the Barmen Declaration, it is the task of the whole Christian community to remind of this righteousness. Jesus enters history as a poor man, exposes himself to poverty as an expression of his novel righteousness, identifies with the poor, calls them blessed, and promises them the Kingdom of God. The poor, though, are not only the penniless but in a wider sense the oppressed, miserable and humiliated. In the guise of such poor and miserable people Jesus Christ encounters his church. In this way, poverty virtually becomes the purpose of God's advent in the world - with the consequence that Jesus gives himself as sacrifice on the cross, as the Christ for the rich and the poor.

The point of Jesus turning his attention to the poor is articulated in the Pauline paradox that he as a rich personage became poor for the benefit of his church in order to make them rich through his poverty. With this about-turn the whole Christian congregation of rich and poor are confronted with their need for Christ's mercy. In this encompassing understanding, poverty and wealth become the characteristic of the Christian congregation, which has consequences for the church as well as for the relation of material poverty and material wealth. So also the personalities of the rich and the poor should be recognised, instead of reducing them to their material situation. By making God's righteousness the foundation and main characteristic of its existence, the Christian church allows itself to be confronted with its basic poverty (its guilt) as well as with its wealth (the promised remission of guilt). Righteousness as the attribute of God's being and action unveils human injustice and requires a culture of human truthfulness, also where the economy is concerned.

The third marker may be called the gift of koinonia. The Christian faith professes the efficacy of the Holy Spirit in uniting people of different character to become the church of Jesus Christ. As a holy nation, as the people of God, the church is called to witness to God's existence. Both rich and poor are united in this task.
Their common relation to God and one another transcends their social differences. Reformed theology has made use of the biblical term 'covenant' to explain this twofold relationship. The gift of koinonia is not only directed at diakonia but also at living together in fraternal communion. The poor are not the objects of the rich people's diakonia but are their partners.

As body of Christ with the gift of koinonia both the poor and the rich are commissioned to serve one another. In the spirit of Calvin, this service is first of all remembrance of the God who for the sake of human beings became poor. According to thesis III of the Barmen Declaration, the congregation presents itself as the koinonia in which Jesus Christ is currently at work. The point is that poor and rich remain related to each other. By virtue of their very existence the poor become 'your poor' and serve the rich by reminding them of God's all-embracing mercy. This gift of koinonia, a communio sanctorum, calls for a culture of acclamation and mutual communication. The liturgical, communicative and social shape of the church is part of its witness to the world in which it publicly demonstrates the connection of the proclaimed truth and its practical life.

The wounds of a lack of freedom, injustice and social isolation are healed when people remember freedom, justice and koinonia as gifts of the triune God. The church sees itself as a community of needy people who are waiting for mercy. Dietrich Bonhoeffer lamented the church's lack of a firm anchor: by wanting to be present everywhere it in fact is nowhere. In order to overcome this problem, which can be detected in churches' and ecumenical bodies' resolutions with regard to concrete ethical engagement, a clear definition of the ground on which the church stands is necessary. This definition might consist of remembering its own neediness, of remembering to leave room for the Gospel to speak to the poor and the rich. The fundamental question is what church and theology stand for. The proposals submitted here are a plea for a theologia, or an ecclesia viatorum, that is a church that is conscious of its roots, and that this consciousness will become visible in the contemporary ecumenical situation.

\section{MONEY AND GOOD WORDS}

Reformed Christians focus particularly on concrete human life. Questions of human life, humanity and justice, money and the economic and social circumstances of human lives have always affected the relationship with God and the proclamation of God's message. With the triune God and the Bible as points of departure the reformers addressed the subjects of economic activity and social circumstances. Starting with 'good words' from the Good News and God's commandments - in order to speak 'good words'. Those who know that they owe their lives and their possessions to God are freed from the compulsion to relate only to themselves and their possessions. Others are recognised as a people who also belong to God. Together they stand, as needy people, before the ever-rich God who gives Godself to them. 